\title{
Duygu Durumlarının Farklılaştığı Resimli Çocuk Kitaplarına Yönelik Okuyucu Tepkilerinin İncelenmesi
}

\author{
Seyit ATEŞ \\ Gazi Üniversitesi \\ seyitates@gazi.edu.tr \\ ORCID ID: 0000-0002-4498-0376 \\ Nurhan AKTAŞ \\ Selçuk Üniversitesi \\ nurhan.aktas@selcuk.edu.tr \\ ORCID ID: 0000-0003-0264-5120
}

\begin{tabular}{lrr} 
Araştırma Makalesi & DOI: $10.31592 /$ aeusbed.742584 \\
\hline Geliş Tarihi: 25.05 .2020 & Revize Tarihi: 14.09 .2020 & Kabul Tarihi: 13.10 .2020
\end{tabular}

\section{Atıf Bilgisi}

Ateş, S. ve Aktaş, N. (2020). Duygu durumlarının farklılaştığı resimli çocuk kitaplarına yönelik okuyucu tepkilerinin incelenmesi. Ahi Evran Üniversitesi Sosyal Bilimler Enstitüsü Dergisi, 6(3), 726-745.

\section{ÖZ}

Resimli çocuk kitapları çocukların kişisel ve akademik gelişimimleri için tartışılmaz öneme sahip olmakla birlikte, çocukların kendilerini ve dünyayı anlamalarında ve ifade etmelerinde onlara yardımcı olan önemli bir araçtır. Çocuk kitapları aracılığıyla çocuk, kendi yaşadığı sorunları ve buna eşlik eden duyguları da daha rahat ifade edebilmektedir. Okuyucu karşılaştığı kitapların niteliğine ve onlarla etkileşim biçimine bağlı olarak hissettiği duygunun, içinde bulunduğu duruma uygun olup olmadığını değerlendirebilmektedir. Bununla birlikte okuyucu, duyguları ile düşünceleri ve hatta davranışları arasında ilişkiler olabileceğine yönelik bir anlayış da geliştirebilmektedir. Bu araştırmanın amacı, duygu durumların farklılaştığı resimli çocuk kitaplarında çocukların bu kitaplara yönelik tepkilerini incelemektir. Çalışma, betimsel araştırma modeli ile yürütülmüştür. Araştırmanın çalışma grubunu, Ankara'da bir özel okulda ikinci sınıfa devam eden 28 öğrenci oluşturmaktadır. Araştırmada veri toplama aracı olarak, farklı sayıda duygu durumuna yer verdiği belirlenen üç resimli çocuk kitabından ve katılımcıların bu kitaplara yönelik tepkilerinin alınmasına yönelik hazırlanan formlardan yararlanılmıştır. Bu çerçevede, seçilen resimli çocuk kitapları katılımcılarla paylaşılmış, ardından öğrencilerin kitapla ilgili sorulara cevap vermeleri istenmiştir. Katılımcıların sorulara verdikleri cevaplar betimsel analiz tekniği ile çözümlenmiştir. Araştırma sonucunda, katılımcıların duygu durumlarının farklılaştığı kitaplarda yer alan duygu durumlarını anladıkları ve tepki açısından orta düzeyde duygusal tepkiler verdikleri; okur ve metin merkezli tepkilerin dağılımının ise birbirine yakın olduğu görülmüştür. Anahtar Kelimeler: Resimli çocuk kitapları, duygu, okur- tepki teorisi, ilkokul öğrencileri.

\section{An Examination of Readers' Responses to Illustrated Children's Books Which Include Different Emotional States}

\begin{abstract}
As well as their undeniable importance in children's personal and academic development, illustrated children's books are an important tool for helping children to understand and express themselves and the world. By means of children's books, the child can more easily express problems that he experiences and the feelings that accompany these. The reader can evaluate whether or not the emotion that he feels, based on the nature of the books he encounters and on the type of interaction with them, suits the situation that he is in. Furthermore, the reader can develop an understanding of the relationships his emotions can have with his thoughts and even with his behaviours. The aim of this study is to examine children's responses towards illustrated children's books which include different emotional states. The study was conducted with a descriptive research model. The study group of the research consisted of 28 students attending second grade in a private school in Ankara. As the data collection tool of the study, three illustrated children's books determined to include a different number of emotional states, and forms prepared with the aim of obtaining participants' responses related to these books, were utilised. Within this framework, the selected illustrated children's books were shared with the participants, and then the students were requested to give answers to questions related to the books. The responses given by the participants were analysed with the descriptive analysis technique. As a result of the study, it was seen that the participants understood the moods included in the books in which there were different emotional states, that in terms of reactions, they showed a moderate level of emotional responses, and that the distributions of reader- and text-based responses were similar to each other.
\end{abstract}

Keywords: Illustrated children's books, emotion, reader-response theory, primary school students 


\section{Giriş}

Resimli çocuk kitaplarının her yaş grubuna hitap eden, öğrenmenin yanı sıra eğlenceyi de içinde barındıran, eşsiz bir görsel ve edebî sanat biçimi sunduğu ifade edilmektedir (Wolfenbarger ve Sipe, 2007). Resimli çocuk kitapları çocuğun dilsel, duyuşsal ve bilişsel öğrenme sürecini desteklemekle birlikte, çocuğun kişilik gelişimine ve demokratik kültürü benimsemesine de katk1 sağladığı bilinmektedir. Resimlerle kelimelerin uyum içinde olduğu bu kitaplar, çocuğun zihninde görsel ögelerle kavramların oluşmasını sağlamakta, duyularını geliştirmekte; nesneleri sınıflandırma, gruplandırma, hatırlama ve dikkat etme gibi bilişsel süreçlerinin gelişimini desteklemektedir (House ve Rule, 2005, Tuğrul ve Feyman, 2006, Lavender Nicholas, 2007, Veziroğlu ve Gönen, 2012). Çocukların kişisel gelişimleriyle birlikte akademik gelişimleri için de önemli olan bu kitaplar; çocukların kendilerini ve dünyayı anlamalarında ve ifade etmelerinde de onlara yardımcı olan bir önemli bir kaynaktır (Lnych-Brown ve Tomlinson, 1999). Bu kitaplarda anlatılan olayları ve kahramanları zihninde canlandıran çocuğun hayal gücü gelişmeye başlar (Temple, Martinez ve Yokota, 2006). Çocuk, kitapta yer alan kahramanlarla kendisi arasında özdeşim kurduğu için, anlatılan olaylardan ve kahramanların verdiği tepkilerden etkilenir. Bu sayede, yanlış olan kötü ve çirkin duygulardan uzak durması gerektiğini anlar, iyi ve doğru değerlere yönelir (Sever, 2003).Yani çocuk kitapları, içeriğindeki olaylar ve yaşantılar yoluyla çocuğa gerçek hayatı ve başka hayatları öğretir. Bu sayede çocuk, gerçek hayatı tanımaya başlar, kendisine ve diğer insanlara değer vermeyi öğrenir, sorumluluk kazanır. Bu da çocuğun kişilik gelişimine yardımcı olmakla birlikte (Aslan, 2007) ebeveynlerin de erken yaşlarda çocuklarına kazandırmak istedikleri değerlerin başında gelmektedir (Aric1 ve Bartan, 2020).

Çocuk edebiyatında karakterler, duygu ve düşünceleriyle insan gerçeği niteliğinde çocuğun karşısına çıkmaktadır. Sözcükler ve resimler ustalar sayesinde, çocuğun yaşamında tamamlayıcı bir etkiye sahip olur. Kişilerin yaşamlarında jest ve mimikleriyle, beden dilini kullanarak ifade ettikleri bazı duygular; yazılı ürünlerde sözcük ve resimlere dönüşür, hayat bulur. Kişilerin yaşamında sahip olduğu duygular, kitap sayfalarında açı̆̆a çıkar. (Sever, 2003). Çocuklar ayrıca resimli kitapları okurken kitapta karşılaştığı olaylar, durumlar ve rollerin farkına vararak, hissettiği bazı duyguları anlamlandırabilir, yorumlayabilir ve empati kurmayı öğrenir (Üstün, 2007). Bütün bunlar sağlıklı bir okuma sürecinde çocuğun nitelikli edebi ürünlere tepkide bulunmasına firsatlar sunularak gerçekleştirilebilecek kazanımlardır. Çocuk, okuma sürecinde çevresinde bulunan görsel veya sözel uyarıcılar ile etkileşimde bulunur, onları anlamlandırmaya çalışır ve tepki verir. Okumanın amacı anlaşılanlar üzerine anlam kurmak olduğundan bu süreçte metin ve okur arasında gerçekleşen etkileşim okurun ön bilgilerine, deneyimlerine ve ilgilerine dayalıdır. Okuma yaklaşımları okumaya farklı anlamlar yüklediğinden okuma eylemi ve okuyucunun süreçteki rolleri de buna göre değişmektedir (Akyol, Yıldırım, Ateş ve Çetinkaya, 2013).Literatürdeki farklı yaklaşımlardan Rosenblatt'ın okur tepki teorisi bu araştırmanın teorik temelini oluşturmaktadır.

Rosenblatt (1988), okur ile metin arasındaki ilişkiyi ifade etmek için "transaction" (dönüşüm) terimini kullanmıştır. Buna göre her okuma eylemi, belirli bir zaman aralığında ve bağlamda metin ve okuyucu arasında gerçekleşen bir etkileşim biçimidir. Her okuma sürecinde çeşitli unsurların veya faktörlerin bulunduğunu belirten Rosenblatt (1994) anlam kurmanın sadece metne ya da okuyucuya dayalı olarak gerçekleştirilmediğini, yazar, okur ve kültürel çevre arasında dinamik bir ilişkiye bağlı olarak anlamda bir dönüşüm yaşandığını vurgulamıştır. Dönüşümsel okuma olarak adlandırılan bu teoride metinle ilgili diğer metinler, her farklı deneyim, her farklı ortam ve diğer okuyucuların tepkileri yeni anlamların ortaya çıkmasına neden olur.

Rosenblatt, okur ve metne eşit şekilde önem vererek, okurun durumunun zaman içinde değişebileceğine vurgu yapar. Her okur farklı deneyimlere sahip olduğu için her okumanın da farklı bir okuma olduğu düşüncesini savunur. Yani çocuğun metne yönelik tepkisi üzerinde deneyimlerin ve bulunulan sosyo-kültürel ortamın da etkisi bulunmaktadır (Rosenblatt, 1978). Okurun içinde bulunduğu ortam ve kültür; duygularını, tutumlarını, inançlarını etkileyici bir özelliğe sahip olduğundan onun tepkileri üzerinde de belirleyici olabilir. Bununla birlikte metin, bağlam ve okuyucu unsurlarından birinin değişmesi metne yönelik tepkilerin de değişmesine sebep olmaktadır. 
Nitekim Ateş, Akbay, Yıldırım ve Çetinkaya'nın (2017) yaptıkları çalışmada öğrencilerin hikâye kitaplarıyla olan deneyimleri değiştikçe tepkilerinin de değiştiği gözlenmiştir. Araştırmacılar günlük bir sınıf rutini olarak birinci sınıf öğrencilerine hikâyeler seslendirmiş ve hikâyeler üzerine estetik ve bilgi amaçlı informal konuşmalar yaparak okur tepkilerinin ortaya çıkmasına ve çeşitlenmesine zemin hazırlamışlardır. Estetik amaçlı konuşmaların yapılması karakterlerin duygu durumlarının anlaşılması yanında, okuyucu olarak öğrencilerin kendi duygularını tanıma ve ifade etmesine de katkı sağlamıştır.

Okur tepkilerinin alınmasına yönelik literatür bilgileri (Hickman, 1981;Temple, Martinez ve Yokota, 2006; Wall, 2000) okurların kitaplara yönelik tepkilerinin alınmasının onların bilişsel, etik ve sosyal gelişim açısından farklılıklarının ortaya çıkmasına; ayrıca okurların hikâyelerdeki tema ve karakterler ile olan kişisel etkileşimlerini ve düşünme biçimleri ile dil gelişimlerini görmemize ve sözlü anlatım becerilerinin gelişmesine (Ulusoy, 2017) yardımcı olacağını ortaya koymaktadır. Literatür bilgileri (Ateş, 2013; Craig, Hull, Haggart )ve Crowder, 2001; Dignazio, 1997; Dunst, Simkus ve Hamby, 2012; Dymock, 2007; Gaber-Katz, 1996; Golden ve Gerber, 1990; Hickman, Pollard-Durodola ve Vaughn, 2004; Isbell, Sobol, Lindauer ve Lowrance, 2004; Justice, Meier ve Walpole, 2005; Miller ve Pennycuff, 2008; Riley ve Burrell, 2007; Sipe, 2010; Sipe ve Brightman, 2005, 2006; Ulusoy, 2016) çocuk kitaplarının duygular açısından diğer alanlar kadar incelenmediğini ve çoğu çalışmanın çocukların tepkilerine/yorumlarına ilgisiz kaldığını da (Sipe, 2008) göstermektedir. Söz konusu ihtiyaçtan hareketle tasarlanan bu araştırmada, duygu durumlarının farklılaştı̆̆ 1 resimli çocuk kitaplarına yönelik okur tepkilerinin değişip değişmediğinin incelenmesi amaçlanmışır. Farklı duygu durumlarının yer aldığı resimli çocuk kitaplarında okurların verdikleri tepkilerin değişiminin incelenmesi ve bu tepkilerin duygulara yönelik ele alınması literatürdeki ihtiyaca cevap vermesi açısından bu çalışmayı önemli kılmaktadır. Bu çerçevede çalışmada duygu durumlarının niceliksel olarak farklılaştığı resimli çocuk kitaplarına okurların verdikleri tepkilerin incelenmesinde Hancock (2008, s.424) tarafindan belirlenen okuyucu tepkilerini ortaya çıkarmaya yönelik sorulardan faydalanılmıştır. Sorularla ortaya çıkarılan tepkilerin çözümlenmesiyle araştırmada "Duygu durumlarının niceliksel olarak farklılaştığı resimli çocuk kitaplarına yönelik çocuk okurların tepkileri nasıldır?” sorusuna cevap aranmıştır.

\section{Araştırmanın Deseni}

Yöntem

$\mathrm{Bu}$ araştırma nitel araştırma geleneği içerisinde yer alan betimsel araştırma modeli ile tasarlanmış ve yürütülmüsştür. Betimsel araştırmalar, verilen bir durumu olabildiğince tam ve dikkatli bir şekilde tanımlar (Büyüköztürk, Çakmak, Akgün, Karadeniz ve Demirel, 2014). Duygu durumlarının nicelik olarak farklılaştığı resimli çocuk kitaplarına yönelik çocukların verdikleri tepkiler ortaya çıkarılmaya ve olduğu şekliyle açıklanmaya çalışıldığı için bu çalışma betimsel araştırma modeline uygun olarak tasarlanmıştır.

\section{Çalıșma Grubu}

Araştırmanın çalışma grubunu, Ankara'da bir özel okulda ikinci sınıfa devam eden 17 kız, 11 erkek olmak üzere toplam 28 öğrenci oluşturmaktadır. Çalışma grubunun oluşturulmasında, araştırmaya hız kazandırması açısından kolay ulaşılabilir örnekleme yöntemi kullanılmıştır (Yıldırım ve Şimşek, 2011). Bu örneklem tekniğinde amaç uygun ve gönüllü olan katılımcıları araştırmaya dâhil etmektir (Creswell, 2005). Araştırma yapılacak okulun seçiminde ulaşım imkânı, zaman ve araştırmacılardan birinin okulda öğretmen olarak görev yapması, bu örneklem yönteminin tercih edilmesinde etkili olan unsurlardır.

\section{Veri Kaynakları}

Araştırmanın temel veri kaynağını ulusal ve uluslararası nitelikteki ödüllü resimli çocuk kitaplarına yönelik okurların ortaya koymuş oldukları tepkiler oluşturmaktadır. Bu amaçla öncelikle ulaşılabilen ödüllü resimli çocuk kitapları içerdikleri duygu sayına göre sıralanmıştır. Kitapların ödül 
almış olmasının, okuyucuların kitap tercihinde önemli bir etken olabileceği düşüncesi veri kaynağının bu şekilde belirlenmesinde etkili olmuştur. Veri kaynağı olarak kullanılan ödüllü resimli çocuk kitapları, farklı yıllarda ve bazıları birden fazla ulusal ya da uluslararası ödül almış olan eserlerdir. Bu kitaplar; araştırmacılar tarafından hazırlanan duygu inceleme formları ile incelenmiştir. Kitaplar duygu yoğunlukları bakımından çoktan aza doğru sıralanmış, içerdikleri duygu türü dikkate alınmaksızın sadece duygu sayılarına göre okur tepkilerini almak üzere üç kitap seçilmiştir. Araştırmanın amacı doğrultusunda seçilen bu üç kitap öğrencilere okunmuş, okur tepkilerini almak amaciyla da Hancock (2008, s.424) tarafından belirlenen okuyucu tepkilerini belirlemeye yönelik sorular sorulmuştur.

Araştırmada kullanılan kitapların duygu durumları açısından taşıdığı nitelikler Tablo 1'de gösterilmiştir.

Tablo 1

Kitaplardaki Duygu Durumlarının Dă̆ılımı

\begin{tabular}{cccccccc} 
Köstebek Kuki & \multicolumn{3}{c}{ Piraye'nin Bir Günü } & \multicolumn{3}{c}{$\begin{array}{c}\text { Bütün Gün Esneyen } \\
\text { Prenses }\end{array}$} \\
\cline { 2 - 8 } Desimgular & Retin & Resim & Metin & Resim & Metin & Toplam \\
\hline Sevinç & 25 & 5 & 3 & 1 & - & 1 & 35 \\
Üzüntü & 7 & 2 & 6 & 2 & 1 & 2 & 20 \\
Şaşkınlı & 5 & 1 & 6 & 4 & 1 & 1 & 18 \\
Sevgi & - & 1 & - & - & - & 2 & 3 \\
Öfke & 3 & - & - & - & - & - & 3 \\
Korku & - & - & - & 2 & - & - & 2 \\
Merak & - & 1 & - & - & - & - & 1 \\
Endişe & - & - & - & 1 & - & - & 1 \\
Alay etme & - & 2 & - & - & - & - & 2 \\
Heyecan & 1 & - & - & - & - & - & 1 \\
Act & - & 1 & - & - & - & - & 1 \\
Pişmanlı & 1 & 2 & - & - & - & - & 3 \\
Diğer & - & 1 & - & - & - & - & 1 \\
Toplam & 42 & 16 & 15 & 10 & 2 & 6 & 91 \\
\hline
\end{tabular}

Tablo 1'den ilk iki kitapta duygulara daha çok resimlerde yer verildiği, duygu sayısının diğerlerine göre daha az olduğu "Bütün Gün Esneyen Prenses" kitabında ise duyguların ağırlıklı olarak metinde yer aldığ 1 görülmektedir. Görece diğer duygulardan daha fazla yer verilen sevinç, üzüntü ve şaşkınlık duygularının kitaplara dağılımının toplam duygu sayısı ile paralellik gösterdiği anlaşılmaktadır.

Araştırmada kullanılan kitaplardan ilki, Betül Sayın tarafindan yazılan "Köstebek Kuki" (Günışığı Kitaplığı) isimli çocuk kitabıdır. "Köstebek Kuki” kitabı en fazla duygu durumun yer aldığı kitaptır. Duyguların 16 tanesi metinde, 42 tanesi resimlemede yer almaktadır. Bu kitap, Çocuk ve Gençlik Yayınları Derneği (ÇGYD) tarafından 2007 yılının en iyi resimli öykü kitabı seçilmiştir. Bir köstebeğin, arkadaşlarına yaptı̆̆ 1 haylazlıkları konu edinen kitapta, kaba davranmanın ve şiddete başvurmanın insanı toplumdan nasıl soyutlayacağını, sorunları çözmede sevgi dilinin ne kadar etkili olduğunu ele almıştır.

İkinci resimli çocuk kitabı ise, Arslan Sayman tarafından kaleme alınan ve Deniz Üçbaşaran tarafından resimlenen "Piraye'nin Bir Günü" (Yapı Kredi Yayınları) isimli kitaptır. "Piraye'nin Bir Günü" isimli kitapta, metinde ve resimlemede yer alan duygular birbirine yakın orandadır. Duyguların 10 tanesi resimlemede, 15 tanesi metinde yer almaktadır. Kitap, Çocuk ve Gençlik Yayınları Derneği (ÇGYD) tarafından 2013 yılının en iyi resimli öykü kitabı seçilmiştir. Piraye isimli 
küçük bir kızın bir gün boyunca başından geçen olayların anlatıldığı ve derdini anlatamayan bir eşekle yaşadığı dostluk hikâyesini ele almaktadır.

Üçüncü resimli çocuk kitabı, Carmen Gil tarafindan yazılan "Bütün Gün Esneyen Prenses"(Redhouse Kidz Yayınları) isimli çocuk kitabıdır. Bu kitapta duygu durumlarının diğer kitaplara göre daha az yer aldığı görülmektedir. Duygulardan 6 tanesi metinde, 2 tanesi resimlemede işlenmiştir. Kitap, 2006 yılında İspanya Kültür Bakanlığı tarafından "resimli çocuk kitabı" dalında ikincilik ödülü almıştır. Esnemesi bir türlü durdurulamayan bir prensesin, bütün saraya esnemeyi bulaştırması ve türlü yollar denenmesine rağmen esnemesinin bir türlü geçmemesini konu edinen kitapta arkadaşlığın önemi anlatılmıştır.

Öğrencilerin seçilen kitaplara dair okur tepkilerini ortaya çıkarmak amacıyla Hancock (2008, s.424) tarafindan belirlenen sorulardan faydalanılmıştır. Sorular okurların estetik, deneyimsel, yorumlayıcı ve bilişsel tepkilerini ortaya çıkarmaya yöneliktir. Katılımcılar, kitapların okunmasından sonra aşağıdaki sorulara yazılı olarak cevap vermişlerdir.

1. Bu kitap kendini nasıl hissetmeni sağladı? (estetik)

2. Bu kitabın kendi hayatınla veya tanıdığın biri ile ilgili hatırlattığı şeyler var mı? (deneyimsel)

3. Bu kitapta senin için hangi mesajlar veya anlamlar var? (yorumlayıc1)

4. Eğer kitaptaki karakterlerden biri olsaydın, ne veya neler yapmak isterdin? (bilişsel)

Son olarak Hancock'un (2008) sorularının yer aldığı okur tepki formuna duygulara dair ayrı bir bölüm eklenmiştir. Bu bölümde katılımcılara okunan kitaplara dair metinde ve resimlerde en çok yer verilen duygunun ne olduğu, kahramanın bunu hissetmesinin normal olup olmadığı ve kendilerinin bu duyguyu hangi durumlarda hissettiği sorularına yer verilmiştir.

\section{Veri Toplama Süreci}

Araştırmanın verileri 2016-2017 eğitim-öğretim döneminin bahar yarıyılında toplanmıştır. Veri toplama aşamasının öncesinde araştırmacılardan her biri çocuk kitaplarını ayrı ayrı içerdikleri duygular açısından incelemiş ve sonuçları karşılaştırmışlardır. Araştırmacılar arasında farklılıklar olması durumunda ilgili kitaplar birlikte değerlendirilerek kitapta yer aldığı düşünülen duygulara ilişkin nihai karar verilmiştir. İkinci aşamada araştırmacılardan biri kendi okulunda, seçilen kitapları öğrencilere okumuş ve okur tepkilerini belirlemeye yönelik hazırlanmış olan soruları katılımcılardan cevaplamalarını istemiştir.

Uygulamayı yapan araştırmacı, öğrencilerin kitaplara ilişkin bu tür tepki çalışmalarına aşina olmadıklarını bildiğinden asıl uygulama öncesinde Feridun Oral tarafindan yazılan ve resimlenen Kırmızı Kanatlı Baykuş (Yapı Kredi Yayınları) kitabıyla bir farkındalık çalışması yaparak öğrencilerin sürece aşina olmalarını sağlamıştır. Kitap öğrencilere iki kez okunmuş, ardından kitapla ilgili informal konuşmalar gerçekleştirilmiştir. Kitapta yer verilen duygulara dikkat çekmek amacıyla öğrencilere bir form dağıtılmış ve öğrencilerin temel duygulara ilişkin farkındalığını artırmak amacıyla da; Kahraman sorunla karşılaştı̆̆ında neler hissetti?, Böyle hissetmesi normal miydi? Böyle bir durumda sen ne hissederdin? Sorun çözüldükten sonra kahramanın duygularında nasıl bir değişiklik oldu? gibi sorular sorulmuştur.

Asıl uygulamaya geçmeden önce öğrencilerle çalışmayı gerçekleştirecek olan araştırmacı, okur tepkilerin alınacağı kitapları birkaç kez okumuş, öğrencilerin okuma sürecinde ve sonrasında tepkilerini ortaya çıkarmaya yönelik sorular ve yönergelerle ilgili hazırlık yapmıştır. Yapılan hazırlıklar doğrultusunda asıl çalışma grubundan farklı bir öğrenci grubuyla pilot çalışma yapılarak sürece ilişkin öngörü sağlanmıştır.

Bütün bu hazırlıklar neticesinde asıl çalışma grubuyla uygulama şu şekilde gerçekleştirilmiştir: 
İlk olarak öğrencilerin oturma düzeni hikâye dinlemeye uygun şekilde ayarlanmış; sonrasında kitaplarda yer alan konularla ilgili (hayvanların özellikleri vb.) katılımcıların ön bilgileri harekete geçirilmeye çalışılmıştır. Ardından kitaplar öğrencilere gösterilmiş, görsellerden hareketle kitabın içeriği ve karakterlerin özellikleri ile ilgili öğrencilerden tahminde bulunmaları istenmiştir. Bu sırada konu ile ilgili olarak informal konuşmalar gerçekleştirilerek, öğrencilerin aktif katılımına zemin hazırlanmıştır. Öğrenciler fiziksel ve zihinsel olarak dinlemeye hazır hale getirildikten sonra kitap, öğrencilerin resimlerini görebilecekleri bir şekilde tutulmuş ve sesli olarak uygun prozodi ile öğrencilere okunmuştur. Pilot çalışmadan edinilen izlenimlere ve öğrencilerin isteklerine dayalı olarak okumalar iki kez gerçekleştirilmiş ve sonrasında incelemeleri için kitap öğrencilere verilmiştir. Okuma sonrası, öğrenciler kitaptaki resimleri yakından incelemesinin ardından, kitaptaki olaylarda yer verilen duygulara dair informal konuşmalar gerçekleştirilmiştir. Son aşamada ise, Hancock (2008, s.424) tarafından belirlenen sorularla duygulara yönelik soruların yazılı olduğu kâ̆̆gtlar öğrencilere dağıtılmış ve onlardan bu soruları cevaplamaları istenmiştir. Yukarıda açılanan süreç her kitap için farklı günlerde ve farklı oturumlarda gerçekleşmiştir.

\section{Araştırma Etiği}

Araştırma yapılmadan önce, araştırma yapılacak okulun yönetimine çalışma hakkında bilgi verilmiştir. Ardından araştırmaya katılacak olan öğrencilerin ebeveynlerinden, okul yönetiminin bilgisi dâhilinde izin alınmıştır. Çalışma katılımcılarının gönüllülük esasına göre yapılmıştır.

\section{Verilerin Analizi}

Katılımcıların okur tepkileriyle ilgili sorulara verdikleri cevaplar, okur tepkilerinin okur ve metin merkezli olma durumlarına göre düzenlenmesine hizmet eden, Wollman-Bonilla ve Werchadlo (1995, ss.564-565) tarafından geliştirilen sınıflamaya göre çözümlenmiştir. Çözümlemede, yapının yetersizliği nedeniyle Ulusoy (2016) tarafindan yeni bir boyutun (ana fikir) eklendiği güncel yapi kullanılmıştır. Buna göre okur merkezli cevaplar üç, metin merkezli cevaplar ise dört alt başlık altında kategorize edilebilmektedir. Bu çerçevede öğrenci cevapları tek tek okunmuş, okur ve metin merkezli olma durumlarına göre çözümlenerek ilgili alt boyutlar altında toplanan cevapların frekans ve yüzdeleri hesaplanmıştır. Bu yapıda okur merkezli cevapların fazla olması kitabın okur üzerindeki duygusal etkisinin büyük olduğu şeklinde yorumlanmaktadır. Werchadlo (1995, ss.564-565) tarafından geliştirilen ve Ulusoy (2016) tarafından güncellenen yapı şu şekildedir:

\section{Metin merkezli cevaplar}

1. Hikâyeyi yeniden anlatma

2. Karakterleri anlama

3. Soru sorma

4. Tahmin etme

5. Ana fikir*

\section{Okur merkezli cevaplar}

1. Kişisel tepki (düşünceler ve hisler)

2. Hikâye ile deneyimleri arasında bağlantı kurma

3. Hikâyedeki olaylara katılma isteği

Duygularla ilgili soruların yer aldığı bölümde kitapta en çok yer verilen duygunun ne olduğuna, kahramanın bu duyguyu hissetmesinin normal olup olmadığına ve okurun kendisinin bu duyguyu hangi durumlarda hissettiğine dair sorular bulunmaktadır. Bu sorulara dair öğrenci cevapları üzerinde betimsel analizler yapılmış, katılımcı cevaplarının sıklıkları ve cevaplardan alınan örnekler ilgili sorular altında sunulmuştur. 


\section{Geçerlik ve Güvenirlik}

Araştırmada resimli çocuk kitaplarındaki duygu durumlarını analiz etmek için, araştırmacılar tarafından geliştirilen duygu inceleme formu kullanılmıştır. Form için alanında uzman üç akademisyenden görüş alınmıştır. Araştırmanın güvenirliği için resimli çocuk kitapları iki farklı araştırmacı tarafından duygu inceleme formları kullanılarak bağımsız olarak değerledirilmiştir. Araştırmacıların ikilemde kaldığ 1 durumlarda kitaplar birlikte değerlendirilerek kitaptaki duygulara yönelik son karar verilmiştir. Araştırmanın güvenirliği Güvenirlik = Görüş birliği / (Görüş birliği + Görüş ayrılı̆̆g) formülü kullanılarak hesaplanmış ve \% 90 seviyesindeki uyum ile güvenirliğin sağlandığ görülmüştür. Bu formüle göre \% 70 ve üzerindeki değerler yeterli kabul edilmektedir (Miles ve Huberman, 1994).

\section{Bulgular}

Niceliksel olarak duygu durumlarının farklılık gösterdiği kitaplara yönelik okur tepkileri incelenmiş ve elde edilen bulgular kitaplara göre ayrı ayrı tablolar halinde sunulmuştur. İlk kitap duygu durumlarının en fazla olduğu "Köstebek Kuki” kitabıdır. Tablo 2'de katılımcıların “Köstebek Kuki” kitabına yönelik tepkilerinin okur ve metin merkezli dağılımları sunulmuştur.

Tablo 2

Öğrencilerin “Köstebek Kuki” Kitabına Verdikleri Cevapların Dă̆ılımı

\begin{tabular}{lcc}
\hline \multicolumn{1}{c}{ Köstebek Kuki } & F & $\%$ \\
\hline Metin Merkezli Cevaplar & 83 & 52.2 \\
\hline Hikâyeyi yeniden anlatma & 21 & 13.3 \\
Karakterleri anlama & 33 & 21 \\
Soru sorma & --- & --- \\
Tahmin etme & --- & -- \\
Ana fikir & 29 & 18.4 \\
\hline Okur Merkezli Cevaplar & 74 & 47.1 \\
\hline Kişisel tepki & 43 & 27.3 \\
Hikâye ile deneyimler arasında bağlantı & 26 & 16.5 \\
kurma & 5 & 3.3 \\
Hikâyedeki olaylara katılma isteği & 157 & 100 \\
Toplam & & .5 \\
\hline
\end{tabular}

Tablo 2'de "Köstebek Kuki" isimli resimli çocuk kitabına yönelik okur tepkileri incelendiğinde, katılımcıların çoğunluğunun (\% 52.2) metin-merkezli cevaplar verdiği görülmektedir. Öğrenciler büyük oranda (\% 27.3) kişisel tepki kategorisine ait sorulara cevap vermiştir. İkinci sırada ise, karakterleri anlama (\% 21) ile ilgili cevaplar yer almaktadır. Bu durum öğrencilerin kitap karakterlerinin rollerini ve davranışlarını anladıklarını göstermektedir. Tablo 2'ye bakıldığında öğrencilerin soru sormaya ve tahmin etmeye yönelik yazılı cevaplar vermedikleri, çok azının ise hikâyedeki olaylara katılma isteğine yönelik cevaplar verdikleri görülmektedir. Katılımcıların cevaplarında en çok gözlenen kişisel tepki kategorisine dair örnek bir yazı şu şekildedir:

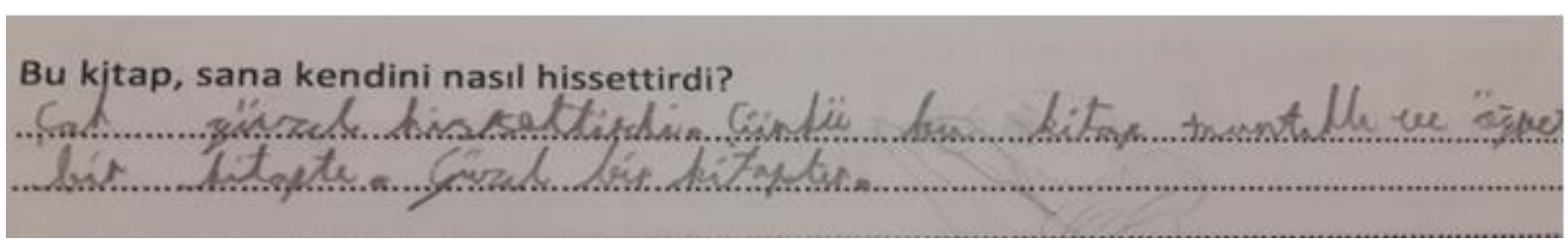

(Çok güzel hissettirdi. Çünkü bu kitap mantıklı ve ögrretici bir kitaptı. Güzel bir kitaptır.)

Örnekte yer alan ifade incelendiğinde, öğrencinin mutlu olma hissini deneyimlediği anlaşılmaktadır. Burada kitabın kurgusu, hikâyedeki tutarlılık ve verilen mesaj okuyucuyu mutlu etmiştir. 
Tablo 3

Öğrencilerin “Köstebek Kuki” Kitabına Yönelik Duygu Durumları

\begin{tabular}{|c|c|c|c|c|c|c|c|c|}
\hline Sorular & $\begin{array}{l}\text { 兰 } \\
\text { 吾 } \\
\text { L }\end{array}$ & 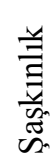 & 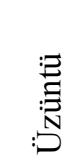 & $\begin{array}{l}\overrightarrow{60} \\
\vec{D} \\
\vec{n}\end{array}$ & 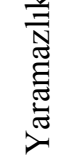 & 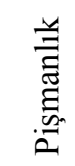 & 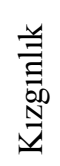 & 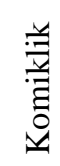 \\
\hline Metinde en çok işlenen duygu hangisidir? & 22 & 1 & 2 & --- & $\begin{array}{ll}-- \\
\end{array}$ & 2 & 1 & --- \\
\hline En çok resmedilen duygu hangisidir? & 19 & 1 & 2 & 1 & 1 & 2 & 1 & 1 \\
\hline \multirow[b]{2}{*}{ Kahramanın bu duyguyu hissetmesi normal midir? } & \multicolumn{4}{|c|}{ Normal } & \multicolumn{4}{|c|}{ Normal Değil } \\
\hline & \multicolumn{4}{|c|}{6} & \multicolumn{4}{|c|}{22} \\
\hline \multirow[b]{2}{*}{ Bu duyguyu hangi durumlarda hissederdin? } & $\begin{array}{l}\text { 兰 } \\
\text { 吾 } \\
\text { 足 }\end{array}$ & \multicolumn{7}{|c|}{$\begin{array}{c}\text { Hediye alınca (6) } \\
\text { Oynayıp eğlendiğimde (5) } \\
\text { Sevinip sevindirdiğimde (3) }\end{array}$} \\
\hline & 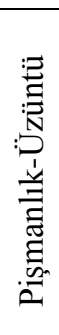 & \multicolumn{7}{|c|}{$\begin{array}{c}\text { Kötülük yapılınca (2) } \\
\text { Arkadaşım benimle oynamadığında (1) } \\
\text { Pişsman olduğumda (1) } \\
\text { Birine yalan söyleyip, o yalanım ortaya } \\
\text { çıkınca (1) }\end{array}$} \\
\hline
\end{tabular}

Tablo 3 incelendiğinde; katılımcıların "Köstebek Kuki" kitabı ile ilgili metinlerde ve resimlemede öne çıan duygunun "mutluluk" olduğu yönünde görüş bildirdikleri görülmektedir. "Üzüntü" ve "pişmanlık" duygusu ise ikinci sırada yer almaktadır. Araştırmacılar tarafından yapılan analizde de kitapta en çok işlenen duygunun "mutluluk/sevinç" duygusu olduğu görülmüştür. Öğrencilerin verdikleri cevaplar ile kitapta yer alan duygu durumlarının örtüştüğg̈ görülmektedir. $\mathrm{Bu}$ durum katılımcıların kitaptaki olayları ve bunlara eşlik eden duyguları anladığı şeklinde yorumlanabilir. Yine katılımcıların büyük bir çoğunluğunun, hikâyenin kahramanı olan Köstebek Kuki'nin hissettiği duyguyu normal bulmamaları da bu düşünceyi destekler niteliktedir. Bunun nedenlerine yönelik bazı katılımcı cevapları şu şekildedir:

“Kuki’nin davranışları normal değildir. Çünkü Kuki sadece canı sıkıldı̆̆ı için arkadaşlarıyla dalga geçiyor. Bu doğru değil."

"Bu duyguyu hissetmesi normal değil çünkü arkadaşlarına hep kötülük yaptı onlarla alay etti."

"Hayır. Çünkü başkalarına zarar verip mutlu olmaya çalışlyor."

Kat1lımc1ların, "Bu duyguyu hangi durumlarda hissederdin?" sorusuna verdikleri cevaplarda

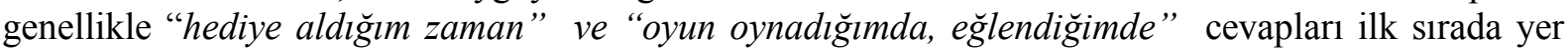
almaktadır. Katılımcıların verdikleri cevaplar arasında kitabın kahramanının yaptığı gibi başkalarının mutsuzluğu üzerine bir mutlu olma halinin örneği görülmektedir. Öte yandan pişmanlık ya da üzüntü ile ilgili ifade edilen görüşlerde katılımcıların genellikle zarar görme ya da zarar verme durumlarında "birisi bana zarar verdiğinde", "benimle alay edildiğinde", "kötülük yapılınca" - bu duyguyu yaşadıkları anlaşılmaktadır. Üzüntü, kitabın ana karakterinin yardımcı karakterlere yaşattığı duyguyken pişmanlık, diğerlerinin üzüntüyü deneyimlemeleri sonrasında kendisinin yaşadığı temel duygudur. 
İkinci kitap duygu durumlarının orta düzeyde yer aldığı "Piraye'nin Bir Günü” isimli kitaptır. Katılımcıların bu kitaba dair ortaya koydukları okur tepkilerinin metin ve okur merkezli dağılımını gösteren tablo aşağıdaki şekildedir.

Tablo 4

Öğrencilerin “Piraye’nin Bir Günü” Kitabına Verdikleri Cevapların Dă̆ılımı

\begin{tabular}{lll}
\hline \multicolumn{1}{c}{ Piraye'nin Bir Günü } & $\mathrm{f}$ & $\%$ \\
\hline Metin Merkezli Cevaplar & 92 & 56.4 \\
\hline Hikâyeyi yeniden anlatma & 20 & 12.2 \\
Karakterleri anlama & 44 & 26.9 \\
Soru sorma & --- & --- \\
Tahmin etme & --- & -- \\
Ana fikir & 28 & 17.1 \\
\hline Okur Merkezli Cevaplar & 71 & 43.5 \\
\hline Kişisel tepki & 29 & 17.7 \\
Hikâye ile deneyimler arasında bağlantı & 26 & 15.9 \\
kurma & & \\
Hikâyedeki olaylara katılma isteği & 16 & 9.8 \\
Toplam & 163 & 100 \\
\hline
\end{tabular}

Tablo 4'te öğrencilerin çoğunluğunun (\% 56.4) “Piraye'nin Bir Günü” isimli kitaba metinmerkezli cevaplar verdikleri görülmektedir. Öğrencilerin cevaplarında ilk sırada (\% 26.9) karakterleri anlamaya yönelik yazılı cevaplar yer alırken, ikinci sırada (\% 17.7) kişisel tepki ve düşüncelerini katarak cevap verdikleri gözlenmektedir. Tablo 4'e bakıldığında, öğrencilerin soru sorma ve tahmin etmeye yönelik hiç cevap vermedikleri görülmektedir. Katılımcıların en fazla oranda cevap verdikleri karakterleri anlama kategorisine dair örnek bir yazı şu şekildedir.

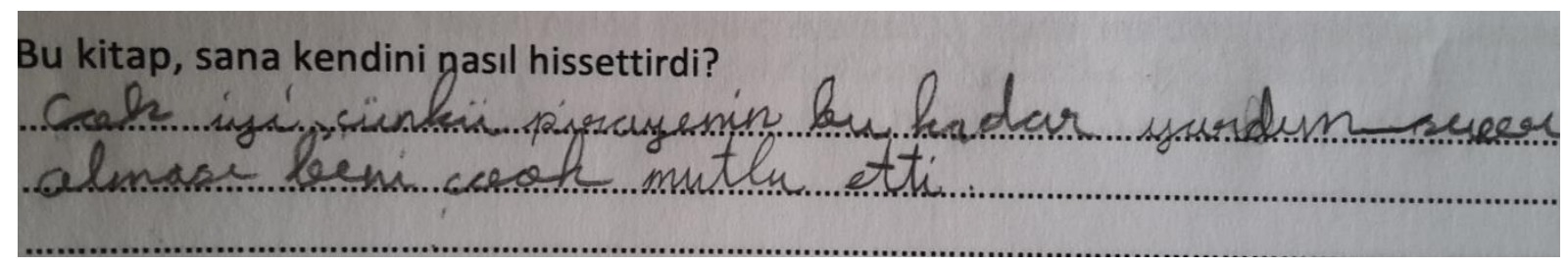

(Çok iyi çünkü Piraye’nin bu kadar yardımsever olması beni çok mutlu etti.)

Örnekteki ifade, katılımcının hikâyede yer alan karakterin rolünü ve davranışlarını anladığına iyi bir örnek oluşturmaktadır.

Tablo 5

Öğrencilerin “Piraye’nin Bir Günü” Kitabına Yönelik Duygu Durumları

\begin{tabular}{|c|c|c|c|c|c|c|}
\hline Sorular & 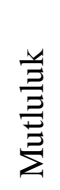 & 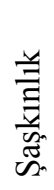 & 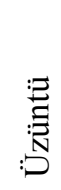 & $\begin{array}{l}\text { DD } \\
\vec{d} \\
\tilde{n}\end{array}$ & 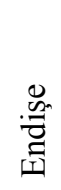 & $\underset{\vec{z}}{\vec{\partial}}$ \\
\hline Metinde en çok işlenen duygu hangisidir? & 5 & 16 & 6 & --- & 1 & --- \\
\hline En çok resmedilen duygu hangisidir? & 7 & 13 & 7 & --- & --- & 1 \\
\hline \multirow{3}{*}{ Kahramanın bu duyguyu hissetmesi normal midir? } & \multicolumn{4}{|c|}{ Normal } & & Normal Değil \\
\hline & \multicolumn{4}{|c|}{24} & & 4 \\
\hline & $\frac{\underline{E}}{\stackrel{\Xi}{\Xi}}$ & \multicolumn{5}{|c|}{$\begin{array}{c}\text { Sürpriz yapılınca ve yaz tatilinde (3) } \\
\text { Hediye alınca, oyun oynayınca (4) }\end{array}$} \\
\hline
\end{tabular}


Bu duyguyu hangi durumlarda hissederdin?

\begin{tabular}{|c|c|}
\hline : & $\begin{array}{c}\text { Biri bana zarar verdiğinde (6) } \\
\text { Kedim gelmediğinde (1) } \\
\text { Bir şeyim kaybolduğunda (1) } \\
\text { Bana diken battığında (1) } \\
\text { Arkadaşımın kalbini kırdığımda (1) }\end{array}$ \\
\hline 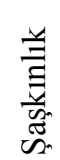 & $\begin{array}{c}\text { Anneniz sizden habersiz bir şey yaparsa } \\
\text { (şaşkınlık) (3) } \\
\text { Arkadaşlarım beni sebepsiz yere dışlarsa (3) } \\
\text { İki kişi kavga ettiğinde (2) }\end{array}$ \\
\hline
\end{tabular}

Tablo 5'e göre katılımcılar "Piraye'nin Bir Günü” kitabı ile ilgili metinlerde ve resimlemede öne çıkan duygunun "şaşkınlık" olduğu yönünde görüş bildirmişlerdir. İkinci sırada ise "üzüntü" duygusu yer almaktadır. Araştırmacılar tarafından yapılan analizde de kitapta en çok işlenen duygunun "şaşkınlık" duygusu olduğu ifade edilmiştir. Öğrencilerin verdikleri cevaplar ile kitapta yer alan duygu durumlarının örtüştüğü görülmektedir. Katılımcıların büyük çoğunluğu kitapta ağırlıklı olarak ele alındığını düşündükleri duygunun kahraman tarafından hissedilmesinin normal olduğunu belirtmişlerdir. Buna yönelik tepkilerden bazıları şu şekildedir:

"Normal çünkü şaşıracak çok şey var."

"Normal çünkü herkes üzülebilir."

"Normal çünkü böyle bir durumda ben de böyle olurdum".

Katılımciların "Bu duyguyu hangi durumlarda hissederdin?" sorusuna verdikleri cevaplar da genel olarak karakterin yaşadığ 1 duygunun - mutluluk, üzüntü, şaşkınlık - neden normal olduğuna dair düşünceleri destekler niteliktedir.

Üçüncü kitap duygu durumlarının az düzeyde yer aldığı "Bütün Gün Esneyen Prenses" isimli kitaptır. Katılımcıların bu kitaba dair ortaya koydukları okur tepkilerinin metin ve okur merkezli dağılımını gösteren tablo aşağıdaki şekildedir.

Tablo 6

Öğrencilerin “Bütün Gün Esneyen Prenses” Kitabına Verdikleri Cevapların Dağılımı

\begin{tabular}{lcc}
\multicolumn{1}{c}{ Bütün Gün Esneyen Prenses } & f & $\%$ \\
\hline Metin Merkezli Cevaplar & 67 & 46.2 \\
\hline Hikâyeyi yeniden anlatma & 22 & 15.1 \\
Karakterleri anlama & 20 & 13.7 \\
Soru sorma & --- & --- \\
Tahmin etme & --- & --- \\
Ana fikir & 25 & 17.2 \\
\hline Okur Merkezli Cevaplar & 78 & 53.7 \\
\hline Kişisel tepki & 54 & 37.2 \\
Hikâye ile deneyimler arasında bağlantı & 18 & 12.4 \\
kurma & 6 & 4.1 \\
Hikâyedeki olaylara katılma isteği & 145 & 100 \\
Toplam & &
\end{tabular}

Tablo 6'da "Bütün Gün Esneyen Prenses" isimli resimli çocuk kitabına yönelik okur tepkileri incelendiğinde, araştırmaya katılan öğrencilerin yarısından fazlasının (\% 53.7) okur-merkezli cevaplar verdiği görülmektedir. Öğrencilerin yazılı cevaplarında ilk sırada (\% 37.2) kişisel tepki kategorisine ait cevaplar yer almaktadır. İkinci sırada ise ana fikir (\% 17.2) ile ilgili yazıll cevaplar gelmektedir. Tablo 6'ya bakıldığında öğrencilerin soru sorma ve tahmin etmeye yönelik hiç cevap vermedikleri, çok azının ise hikâyedeki olaylara katılma isteğine yönelik cevaplar verdikleri görülmektedir. Katılımcıların en fazla oranda cevap verdikleri kişisel tepki kategorisine dair örnek bir yazı şu şekildedir: 


\section{(Mutlu çünkü çok ama çok heyecanlı)}

Örnekteki ifadeden, katılımcının mutlu olma hissini deneyimlediği ve buna heyecan duygusunun eşlik ettiği anlaşılmaktadır. Kitabın içeriği, kitaptaki olayın okuyucuda merak uyandırması ve verilen mesaj okuyucuyu mutlu etmiştir.

Katılımcıların cevaplarında ikinci sırada ana fikir (\% 17.2) ile ilgili cevaplar yer almıştır. $\mathrm{Bu}$ kategoriye dair örnek bir yazı şu şekildedir:

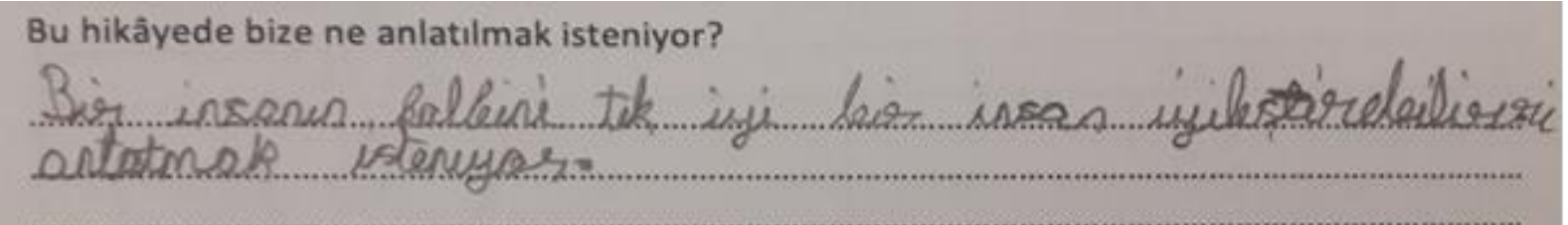

(Bir insanın kalbini tek iyi bir insan iyileştirebilir anlatılmak isteniyor.)

Örnekteki ifade, katılımcıların hikâyede verilmek istenen mesajı anladıklarının bir göstergesidir.

Tablo 7

Öğrencilerin “Bütün Gün Esneyen Prenses” Kitabına Yönelik Duygu Durumları

\begin{tabular}{|c|c|c|c|c|c|c|}
\hline Sorular & $\begin{array}{l}\text { 号 } \\
\text { 总 }\end{array}$ & 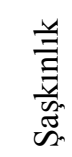 & لص: & $\begin{array}{l}\text { कD } \\
\dot{0} \\
\tilde{n}\end{array}$ & $\underset{\mathscr{I}}{\mathscr{I}}$ & $\begin{array}{l}\vec{z} \\
\frac{\vec{z}}{0} \\
\underline{v}\end{array}$ \\
\hline Metinde en çok işlenen duygu hangisidir? & 4 & 5 & 18 & --- & 1 & --- \\
\hline En çok resmedilen duygu hangisidir? & 4 & 5 & 19 & --- & --- & --- \\
\hline \multirow{2}{*}{ Kahramanın bu duyguyu hissetmesi normal midir? } & \multicolumn{4}{|c|}{ Normal } & & Normal Değil \\
\hline & \multicolumn{4}{|c|}{26} & & 2 \\
\hline \multirow{4}{*}{ Bu duyguyu hangi durumlarda hissederdin? } & 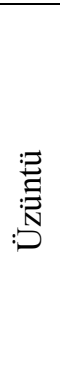 & \multicolumn{5}{|c|}{$\begin{array}{c}\text { Arkadaşım bana zarar verdiğinde (7) } \\
\text { Ailem bana kızdığında (4) } \\
\text { Bir şeyim kaybolduğunda (1) } \\
\text { Bir arkadaşım beni görmezlikten geldiğinde } \\
\text { (1) } \\
\text { Arkadaşlarım beni dışladığında (2) } \\
\text { Birisi bana yalan söylediğinde (1) } \\
\text { Hasta olunca, düşünce (1) } \\
\text { Uykulu olunca (2) }\end{array}$} \\
\hline & 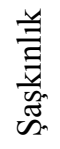 & \multicolumn{5}{|c|}{$\begin{array}{l}\text { Hiçbir durumda hissetmem (1) } \\
\text { Aynı durumu yaşadığımda (2) }\end{array}$} \\
\hline & $\begin{array}{l}\frac{y}{\Xi} \\
\stackrel{\Xi}{\Xi} \\
\sum\end{array}$ & \multicolumn{5}{|c|}{$\begin{array}{l}\text { Hediye alınca (4) } \\
\text { Doğum günümde (1) }\end{array}$} \\
\hline & 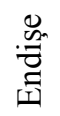 & \multicolumn{5}{|c|}{ Korktuğum zaman (endişe) (1) } \\
\hline
\end{tabular}


Tablo 7'de öğrencilerin "Bütün Gün Esneyen Prenses" isimli kitaba verdikleri tepkilere bakıldığında, metinde ve resimlemede yoğun olarak işlenen duygunun "üzüntü" olduğu yönünde görüş belirttikleri görülmektedir. İkinci sırada ise "şaşkınlık" duygusu yer almaktadır. Araştırmacılar tarafindan yapılan analizde de kitapta en çok işlenen duygunun "üzüntü” duygusu olduğu belirtilmiştir. Öğrencilerin verdikleri cevaplar ile kitapta yer alan duygu durumlarının örtüştüğü görülmektedir. Katılımcıların büyük bir kısmı işaret ettikleri duyguyu kahramanın hissetmesinin normal olduğunu düşünmektedir. Buna gerekçe olarak sunulan görüşlerden bazıları şu şekildedir:

" Normal çünkü çok esneyince insan endişelenir."

"Normal çünkü prenses garipti."

“ Normal çünkü böyle bir durumda herkes aynı şeyi hissederdi."

"Normal çünkü sürekli esniyor."

“Normal çünkü sürekli esnemesi üzülmesi gereken bir durum”

Öğrencilerin, "Bu duyguyu hangi durumlarda hissederdin?" sorusuna verdikleri cevaplarda üzüntü duygusuna yönelik "Arkadaşım bana zarar verdiğinde" cevabı en çok yazılan cevap olarak görülmektedir. "Ailem bana kızdığında" cevabı ikinci sırada yer almıştır.

\section{Sonuç, Tartışma ve Öneriler}

Duygu durumlarının farklılaştığı resimli çocuk kitaplarında ilkokul ikinci sınıf öğrencilerinin okur tepkilerinin incelendiği bu araştırma, Rosenblat'ın okur-tepki teorisi (reading response theory) üzerine kurgulanmıştır. Teoride okumanın okur, yazar (metin) ve sosyokültürel ortamın bir ürünü olduğu ve bu elementlerden birindeki değişikliğin yapılandırılan anlamda farklılığa neden olacağı düşüncesi vurgulanmaktadır. Bu noktada, metinlerdeki duygu durumlarındaki niceliksel değişikliğin okur tepkilerinde nasıl bir değişime neden olacağı düşüncesi bu araştırmanın hareket noktasını oluşturmuştur. $\mathrm{Bu}$ amaçla incelenen ödüllü resimli çocuk kitaplarından duygulara "çok-orta-az" yer verme durumlarına göre üç kitap seçilmiş, bu kitaplar öğrencilere okunmuş ve okur tepkileri alınmıştır. Seçilen kitaplardan "Köstebek Kuki" kitabı duygulara en fazla yer verilen kitapken, "Piraye'nin Bir Günü" ikinci, "Bütün Gün Esneyen Prenses" ise üçüncü sırada yer almaktadır. Uygulama öncesi kitaplar incelendiğinde, duyguların niceliksel değişiminin yanı sıra bu üç kitapta "sevinç, üzüntü, şaşkınlık, sevgi ve öfke" duygularına daha çok görsellerde; "korku, merak, endişe, alay etme, heyecan ve pişmanlık" gibi duygulara ise daha çok metinde yer verildiği görülmüştür.

Duygu durumlarının niceliksel olarak farklılaşmasının okur tepkilerinde nasıl bir değişime neden olduğunu görmek amacıyla yapılan çalışmada, analizler sonucu ulaşılan bulgular metin değiştiğinde okur tepkilerinin değişebileceğini belirgin bir şekilde ortaya koymuştur. Ulaşılan bu sonuç literatürdeki farklı metinlere dair okurların farklı tepkiler sergilediğini gösteren araştırma sonuçlarıyla benzerlik göstermektedir (Örn., Pantaleo, 2007; Serafini, 2005; Ulusoy, 2016; Yekeler ve Ulusoy, 2017; Sultan, Ateş ve Çetinkaya, 2017). Ancak bu değişim kitaplarda yer alan duyguların sayısı paralelinde aynı yönde ve doğrusal olarak gözlenmemiştir. Katılımcıların kitaplara verdikleri tepkiler birlikte değerlendirildiğinde ilk iki kitaba yönelik tepkilerin daha metin merkezli, son kitaba yönelik tepkilerinse daha çok okur merkezli olduğu görülmektedir. Köstebek Kuki isimli kitabın metin ve resimlemelerinde yaklaşık 60, Piraye'nin Bir Günü'nde ise 25 duygu tespit edilmiştir. Duyguların daha az olduğu ikinci kitaba yönelik metin merkezli cevapların sayısında önemli bir artış gözlenirken içinde yaklaşık 10 duygunun yer aldığı son kitaba - Bütün Gün Esneyen Prenses - gelindiğinde; ilk iki kitaptaki gözlemden hareketle oluşan beklentinin tam tersi yönünde bir değişim gözlenmiştir. $\mathrm{Bu}$ kitaba dair öğrenciler dikkat çekici bir oranda daha fazla okur merkezli tepkiler ortaya koymuşlardır. Bulgular net olarak metin değiştiğinde kurulan anlamların değişebileceğini göstermiştir. Ancak bu bulgular, Rosenblatt'ın (1994) okur-tepki kuramının sacayağını oluşturan okur, metin ve ortam üçlüsünden "metinde" gözlenen nicel değişimlerin kurulan anlamlar üzerindeki değişimi açıklamada yetersiz kalacağını da ortaya koymaktadır. Çünkü duyguların sayısındaki doğrusal azalma okur ya da 
metin merkezli tepkilerde doğrusal bir değişimle sonuçlanmamıştır. Bu durum, anlamın değişmesinde metinlerde gözlemlenen niceliksel değişikliklerin güçlü bir etken olmadığı şeklinde yorumlanabilir. Ya da bir başka açıdan anlam kurmayı etkileyebilecek niceliksel değişkenlerden daha güçlü başka niteliklerin olabileceği anlamına gelebilir. Nitekim duygular açısından ele alındığında duygulara ne sıklıkla yer verildiğinden ziyade duygu durumlarının nasıl ve ne şekilde verildiği, niteliği, okurun ortaya konan duyguları tanıyıp tanımaması, kabul edip etmemesi gibi durumlar da etkili olmuş olabilir. Örneğin Köstebek Kuki kitabında ana karakter sıklıkla mutlu olmaktadır ve bu, metin ile resimlerde oldukça fazla yer almaktadır. Ancak kitapta en çok gözlenen mutluluk duygusunu karakterin yaşamasını okur kabul etmemektedir. Başkalarının mutsuzluğu üzerine yaşanan bu mutluluk okurun öfkelenmesine bile neden olabilmektedir. Genelde ya da normalde hikâyelerdeki ana karakterle özdeşim kurulur ve ana karakterin mutlu olması okuyucuyu da mutlu eder. Ancak bu hikâyede yaşananlar ve yaşananlara eşlik eden duygular, okuyucunun özdeşim kuracağı karakteri de bütün bunlar karşısında hissedeceği duyguyu da değiştirebilmektedir. Bu noktada duygularla ilgili nicel değişimlerden ziyade yaşanılan duygunun hangi bağlam içerisinde yaşandığının ve kabul edilebilir olup olmadığının çok önemli bir değişken olarak ortaya çıtığını söyleyebiliriz. İkna edicilik ya da kabul edilebilirlik ile duruma uygun olma (De Beaugrande vee Dressler, 1981) önemli metinsellik ölçütlerinden biridir. Coşkun (2007), ikna edicilik başlığı altında her okurun metni kendi kültürü ve toplumsal gerçekleri ile yorumladığına ve anlamlandırdığına vurgu yapar. Esasında yazarın mesajının okur tarafından kabul edilip edilmediği ve duruma uygun olup olmadığıyla ilgili olan bu ölçütleri karakterin hissettiği duygunun okur tarafından nasıl değerlendirildiğini anlamak için de kullanabiliriz.

Araştırmada ulaşılan sonuçları değerlendirirken teorideki bir başka değişken olan "okur"dan da söz etmek gerekmektedir. Edebi eser okuru harekete geçmeye davet ederken okuyucu ile metin arasında geniş bir hareket alanı bulunmakta, okur bu süreçte deneyimleri ve birikimiyle metnin öznel anlamını inşa etmektedir (Özdemir, 2017). Çalışma okurun önemli ölçüde değişim gösterebileceği kadar geniş bir zamana yayılmamıştır. Bu nedenle okurun ilk metinden son metne kadar üç haftalık süreçte geçirdiği değişimlerin bu çalışmada gözlenen okur tepkileri üzerinde bir farklılığa sebep olup olmadığı merak konusudur. Okunan, sonraki her metne dair tepkiler önceki metinler ve onlara verilen tepkilerden etkilenmiş midir bilinmemektedir. Zira Ateş, Akbay, Yıldırım ve Çetinkaya'nın (2017) yaptıkları çalışmada öğrencilerin hikâye kitaplarıyla olan deneyimleri arttıkça/değiştikçe tepkilerinde farklılıklar olduğu gözlenmiştir. Ancak söz konusu çalışma 6-7 aylık bir süreçte okur tepkilerinin değişimini izlemeye yönelik bir çalışmadır.

Rosenblatt (1999) "Edebi ürün düşük duygusal etkiye sahipse, tartışmanın hepsi boş laf kalabalığı olur." diyerek okuyucu tepkilerinin önemine vurgu yapmıştır. Bu çalışmada katılımcıların kitaplara dair okur ve metin merkezli tepkilerindeki dağılımın \% 45 ila \% 55 arasında bir değişim gösterdiği gözlenmektedir. Okur ve metin merkezli eğilimin birbirine yakın oranlarda bir seyir izlemesi duygu durumları farklılaşmakla birlikte kitapların okur üzerindeki duygusal etkilerinin orta düzeyde olduğu şeklinde yorumlanabilir. Nitekim aynı sınıf düzeyinde, iki kitap ile gerçekleştirdiği araştırmasında Ulusoy (2016), yaklaşı \% 64 düzeyinde ortaya çıkan okur merkezli tepkilerin yüksek düzey duygusal etkiye sahip olduğunu ifade etmiş̧ir. Bu çalışmada ise okur ve metin merkezli tepkilerin dengeli bir dağılım gösterdiği gözlenmiştir. Rosenblatt'a (1978) göre çocuğun metne yönelik tepkisi üzerinde deneyimleriyle birlikte ortamın da etkisi bulunmaktadır. Bu üç unsurdan birinin değişmesi tepkilerin değişmesine neden olabilir. Bu çalışmada metinlerdeki duyguların niceliksel olarak değişmesinin oluşturacağı etkiler odak noktasını oluşturmuştur. Ancak kitaplarla/metinlerle ilgili yukarıda tartışılan bazı hususların çalışma kapsamı dışında bırakılması ve kontrol altına alınmamış olması önemli bir sınırlılık olarak ortaya çıkmış ve tepkilerde gözlenen farkın söz konusu teori temelinde anlaşılmasını güçleştirmiştir. Bu türdeki çalışmaların özellikle ikna edicilik, duruma uygun olma, hikâyelerin oluşturduğu bağlam, hikâyelerde ele alınan problem, karakterler, duyguların resimlerde ve metinlerle yer alma durumları ile birlikte nasıl ele alındıkları gibi bazı önemli değişkenler açısından metinlerin kontrol altına alınmasıyla tekrarlanması daha açıklayıcı ve anlaşılır sonuçların ortaya konmasına katkı sağlayacaktır. 
Çalışmanın odaklandığı bir başka husus kitaplarda sunulan duygu durumlarının katılımcılar tarafından anlaşılıp anlaşılmadığı ve yaşananlar karşısında kahramanın bu duyguları hissetmesinin okuyucular tarafından nasıl algılandığıdır. Bu amaçla yapılan analizler katılımcıların, Köstebek Kuki kitabında "mutluluk", Piraye'nin Bir Günü ve Bütün Gün Esneyen Prensens kitabında "şaşkınlık ve üzüntü”, duygularını ön plana çıkardıklarını göstermiştir. Kitapta ön plana çıkan duyguların, öğrencilerin verdikleri cevaplarla örtüştüğü görülmektedir. Öğrencilerin kitaplarda yoğun olarak işlenilen duyguları tespit etmekte başarılı oldukları anlaşılmaktadır. Öğrencilere bu duyguları kahramanların hissetmesinin normal olup olmadığı sorulduğunda sadece bir kitap (Köstebek Kuki) için kahramanın bu duyguyu hissetmesinin normal olmadığını söylemişlerdir. Öğrencilerin açıklamalarından metindeki bağlamı ve duygu durumlarını anladıkları ve kendi deneyimlerinden hareketle empati kurarak cevap verdikleri anlaşılmaktadır. Nitekim kendilerinin söz konusu duyguyu hangi durumlarda hissettiklerine dair sorulan soruya katılımciların verdikleri cevaplar ile kitaba yönelik tepkilerde kişisel tepki, deneyimle bă̆ kurma ve karakteri anlama alt boyutlarında yüksek frekansların gözlenmesi de bu düşünceyi destekler niteliktedir. Çocuklar kitaplarla kurdukları ilişki sayesinde karşılaştıkları olaylar, durumlar ve rollerin farkına vararak, hissettiği bazı duyguları anlamlandırarak empati kurmayı da öğrenmektedirler (Üstün, 2007).

Rosenblat (1994) bilgi ve estetik olmak üzere iki amaçla okuma yaptığımızı, çocuklarda okuma zevk ve alışkanlığını geliştiren okumanınsa estetik okumalar olduğunu ifade etmektedir. Lipman (2003) da bu düşünceyi destekler nitelikte duyguların insanların düşünce ve davranışlarını etkileyebileceğini belirtmektedir. Araştırmalar (Ateş, 2011) ve deneyimlerimiz okullarımızda genellikle bilgi amaçlı okumalar yaptığımızı göstermektedir. Oysa mutlaka bilgi amaçlı bir okuma yapılacaksa bile yani kitapta verilen mesaja gidilmek isteniyorsa; bunu, duygular üzerinden de gerçekleştirmek mümkündür. Bu öngörü, aynı zamanda hem uygulamaya hem de araştırmaya yönelik bir öneri olarak da değerlendirilebilir. Rosenblatt'a $(1978,1999)$ göre estetik tepkiler beş duyu ve hisler üzerine daha fazla vurgu yapar. Bu bağlamda okuma zevk ve alışkanlığının gelişmesinde estetik tepkilere, diğer bir ifade ile kitaplarla kişisel bağlantılar oluşturmaya, hikâyedeki olaylara katılma isteği oluşturacak şekilde kişisel tepkilere yer vermeye yönelik çalışmalar yapılması gerektiği söylenebilir. Bu çalışma, estetik açıdan kitaplarla yeterli deneyime sahip olmayan öğrencilerle ve ödüllü resimli çocuk kitapları kullanılarak gerçekleştirilmiştir. Okur tepkilerinin daha iyi anlaşılması ve öğretim sürecinde gerek okuma zevk ve alışkanlığının geliştirilmesi gerekse düşünme ve anlama becerilerini içeren okur tepkilerinin çeşitlendirilmesi ve geliştirilmesi adına okurun, metnin ve ortamın etkilerini test etmeye yönelik bu ögelerin niteliklerinin değiştiği ve bunun okur tepkileri üzerine etkisinin nasıl olduğunu belirlemeye yönelik daha fazla çalışma yapılması gerektiği söylenebilir. Araştırma farklı duygu durumlarının yer aldığı çocuk kitaplarıla üç haftalık bir zaman diliminde gerçekleştirilmiştir. İlkokul öğrencilerinin, aynı/benzer duyguların yer aldığı çocuk kitaplarına yönelik tepkileri ve bu metinlerle olan kişisel etkileşimlerini belirlemeye yönelik daha uzun süreli uzamsal bir çalışma yapılabilir.

\section{Kaynaklar}

Akyol, H. (2011). Türkçe öğretim yöntemleri. Ankara: Pegem A.

Arıcı D. ve Bartan, M. (2020). Çocuğu okul öncesi eğitime devam eden annelerin çocuklarına değer edindirme sürecine yönelik görüşleri, Ahi Evran Üniversitesi Sosyal Bilimler Enstitüsü Dergisi. 6 (1), 279-294.

Aslan, C. (2007). Yazınsal nitelikli çocuk kitaplarının çocuğun okuduğunu anlama ve yazılı anlatım becerilerine etkisi. Ë̌itim Araştırmaları, 27, 15-29.

Ateş, S. (2011). İlköğretim beşinci sinlf Türkçe dersi öğrenme-öğretme sürecinin anlama öğretimi açısından incelenmesi. Yayımlanmamış Doktora Tezi. Gazi Üniversitesi Eğitim Bilimleri Enstitüsü, Ankara. 
Ateş, S. (2013). İlkokulda peritextual okumadan metinlerarası okumaya resimli hikâye kitabı okuma süreci. International Journal of Human Science, 10, 1567-1585.

Ateş, S., Akbay, F., Yıldıım, K. ve Çetinkaya F.Ç. (2017). The effects of storytelling and story reading on first grade students' story comprehension and retelling skills. 20 th European Conference on Literacy, (3-6 July) Madrid, Spain (Oral Presentation).

Barthes, R. (1975). The pleasure of the text (R. Miller, Trans.). NY: Hill and Wang

Büyüköztürk, S., Çakmak, E. K., Akgün, Ö. E., Karadeniz, S. ve Demirel, F. (2014). Bilimsel araştırma yöntemleri. Ankara: Pegem-A.

Craig, S., Hull, K., Haggart A. and Crowder, E. (2001). Storytelling: Addressing the literacy needs of diverse learners. Teaching Exceptional Children. 33 (5), 46-51.

Creswell, J. W. (2005). Educational research: Planning, conducting, and evaluating quantitative and qualitative research (Second edition). New Jersey: Pearson Education, Inc.

De Beaugrande, R. A. D. and Dressier W. (1981). Introduction to text linguistics. London: Longman Group Company.

Dignazio, J.A. (1997). An examination of the critical reading of fifth graders who have been presented with either a single version or parallel versions of a story episode. Doctoral Dissertation. Temple University.

Dunst, C.J., Simkus, A. and Hamby, D.W. (2012). Children's story retelling as a literacy and language enhancement strategy. Center for Early Literacy Learning Reiews, 5 (2), 1-14.

Dymock, S. (2007). Comprehension strategy instruction: teaching narrative text structure. The Reading Teacher, 61, 161-167.

Gaber-Katz, E. (1996). The use of story in critical literacy practice. Gender and Educational Journal, 8, 49-60.

Golden, J.M., and Gerber, A. (1990). A semiotic perspective of text: The Picture story book event. Journal of Reading Behavior, 22, 203-219.

Hancock, M. R. (2008). A celebration of literature and response: Children, books, and teachers in K-8 classrooms. Columbus, Ohio: Pearson.

Hickman, J. (1981). A new perspective on response to literature: Research in an elementary school setting. Research in the Teaching of English, 15, 344-354.

Hickman, P., Pollard-Durodola, S. and Vaughn, S. (2004). Storybook reading: Improving vocabulary and comprehension for English-language learner. The Reading Teacher, 57, 720-730.

House, C. and Rule, A. (2005). Preschoolerse 1deas of what makes a picture book 1llustration beautiful". Early Childhood Education Journal, 32 (5), 283-290.

Isbell, R., Sobol, J., Lindauer, L. and Lowrance, A. (2004). The effects of storytelling and story reading on the oral language complexity and story comprehension of young children. Early Childhood Education Journal, 32, 157-163.

Iser, W. (1978). The act of reading: A theory of aesthetic response. Baltimore: The Johns Hopkins University Press. 
Jalongo, M.P. (2004). Young children and picture books. National Association for the Education of Young Children, Washington DC.

Justice, L.M., Meier, J. and Walpole, S. (2005). Learning new words from storybooks: An efficacy study with at-risk kindergartners. Language, Speech And Hearing Services In Schools, 36, $17-$ 32.

Lavender Nicholas, J. (2007). An exploration of the impact of picture book illustrations on the comprehension skills and vocabulary development of emergent readers. Graduate Faculty of the Louisiana State University.

Lipman, M. (2003). Thinking in education (Second Edition). New York: Cambridge.

Lynch-Brown, C. ve Tomlinson, C.M. (1999). Essentials of children's literature (Third edition). Boston: Allyn and Bacon.

Martin, W. (1956). Storytelling fort he gifted child. The Reading Teacher, 9, 226-230.

Miller, S. and Pennycuff, L. (2008). The power of story: Using storytelling to improve literacy learning. Journal of Cross-Disciplinary Perspectives in Education, 1(1), 36-43.

Miles, M. B., and Huberman, A. M. (1994). Qualitative data analysis. Thousand Oaks.

Morrow, L M., Pressley, M., Smith, J. K. and Smith, M. (1997). The effect of a literature-based program integrated into literacy and science instruction with children from diverse backgrounds. Reading Research Quarterly, 32 (1 ), 54-76.

Özdemir, E. (2017). O iyi kitaplar olmasaydı (3. Basım). Ankara: Bilgi Yayınevi.

Pantaleo, S. (2007). Scieszka's the Stinky Cheese Man: A tossed salad of parodic reversions. Children's Literature in Education, 38 (4), 277-295.

Peck, J. (1989). Using storytelling to promote language and literacy development. The Reading Teacher, 43 (2), 138-141.

Poulet, G. (1980). Criticism and the experience of interiority. In J. P. Tompkins (Ed.), Readerresponse criticism: From formalism to post-structuralism (pp.41-49). Baltimore: The Johns Hopkins University Press.

Reese, C. (1996). Story development using wordless picture books. The Reading Teacher, 50, 172175.

Riley, J. ve Burrell, A. (2007). Assessing children's oral storytelling in their first year of school. International Journal of Early Years Education, 15 (2), 181-196.

Rosenblatt, L.M. (1978). The reader, the text, the poem: The transactional theory of the literary work. Carbondale: Southern Illinois University Press.

Rosenblatt, L. M. (1994). The reader, the text, the poem: The transactional theory of the literary work. Carbondale: Southern Illinois University Press. 
Rosenblatt, L. M. (1999). Literature as exploration. NY: The Modern Language Association of America.

Serafini, F. (2005). Voices in the park, voices in the classroom: Readers responding to postmodern picturebooks. Reading Research and Instruction, 44 (3), 47-64.

Sever, S. (2003). Çocuk ve edebiyat. Ankara: Kök.

Sipe L.R. (2010). Learning from illustrations in picturebooks. Leitura em Revista Catedra UNESCO de Leitura PUC-Rio, 1, 71-84

Sipe, L. R. (1993). Using transformations of educational stories: Making the reading-writing connection. The Reading Teacher, 47, 18-26.

Sipe, L. R. (1996). The construction of literary understanding by first and second graders in response to Picture strybook readalouds. Doctoral Dissertation. Ohio State University.

Sipe, L. R. (2008). Storytime: Young children's literary understanding in the classroom. NY: Teachers College Press.

Sipe, L. R. ve Brightman, A. (2005). Young children's visual meaning-making during readalouds of Picture storybooks. National Reading Conference Yearbook, 54, 349-361.

Sipe, L. R. and Brightman, A. (2006). Teacher scaffolding of first-graders' literary understanding during readalouds of fairytale variants. National Reading Conference Yearbook, 55, 276-292.

Squire, J. and Squire, J.R. (1955). Responses to a short story. The Reading Teacher Journal, 9, 30-35.

Temple, C., Martinez, M. And Yokota, J. (2006). Children's books in children's hands: An introduction to their literature. NY: Pearson.

Tuğrul, B. ve Feyman, N. (2006). Okul öncesi çocukları için hazırlanmış resimli öykü kitaplarında kullanılan temalar. II. Ulusal Çocuk ve Gençlik Edebiyatı Sempozyumu-Gelişmeler, Sorunlar ve Çözüm Önerileri (s. 387-392). Ankara: Ankara Üniversitesi.

Ulusoy, M. (2016). Resimli çocuk kitapları ve okur-tepki teorisi. İlköğretim Online, 15(2), 487-497.

Ulusoy, M. (2017). İlkokul öğrencilerinin resimli çocuk kitaplarını sözlü olarak anlatma becerilerinin incelenmesi. Ahi Evran Üniversitesi Sosyal Bilimler Enstitüsü Dergisi, 3 (1), 29-43.

Üstün, E. (2007). Okul öncesi çocukların okuma yazma becerilerinin gelişimi. İstanbul: Morpa Yayınları.

Veziroğlu, M. ve Gönen, M. (2012). Resimli çocuk kitaplarının M. E. B. Okul Öncesi Eğitim Programı "ndaki kazanımlara uygunluğunun incelenmesi. Eğitim ve Bilim, 37 (163), 226-238.

Yekeler A. D. ve Ulusoy, M. (2017). İlkokul öğrencilerinin bilgi verici resimli çocuk kitaplarına yönelik tepkileri. Anadolu Kültürel Araştırmalar Dergisi, 1 (2), 20-39.

Yuran, S., Ateş, S. ve Çetinkaya, F.Ç. (2017). Resimli çocuk kitaplarl, dijital hikâyeler ve okur tepkileri. 1. Uluslararası Sınırsız Eğitim ve Araştırma Sempozyumu, 24-26 Nisan, Antalya. 
Wall, H. (2000). How do authors do it? Using literature in a writer's workshop. The New Advocate, $13(2), 157-170$.

Wolfenbarger, C.D. ard Sipe, L.R. (2007). A unique visual and literary art form: Recent research on picturebooks. Language Arts, 83, 273-280.

Wollman-Bonilla, J. and Werchadlo, B. (1995). Literature response journals in a first-grade classroom. Language Arts, 72, 562-570. 


\section{Extended Abstract}

\section{Introduction}

Illustrated children's books are stated to offer a unique visual and literary art form that appeals to readers of all ages and includes many levels of learning and entertainment (Wolfenbarger \& Sipe, 2007). By means of children's books, the child can more easily express problems that he experiences and the feelings that accompany these. In this study, the aim is to examine whether readers' responses vary with regard to illustrated children's books which include different emotional states. Within this framework, for the examination of responses given by readers to illustrated children's books in which emotional states differed quantitatively, the questions proposed by Hancock (2008, p.424) for revealing readers' responses were utilised in the study. For analysing the responses revealed with the questions, answers to the question "What are child readers' responses to illustrated children's books in which emotional states differ quantitatively?" were sought in the research.

\section{Method}

This study was designed and conducted with the descriptive research model, one of the qualitative research methods. The study group of the research consisted of 28 students (17 girls and 11 boys) attending second grade in a private school in Ankara. As the data collection tool of the study, three illustrated children's books determined to include a different number of emotional states, and forms prepared with the aim of learning participants' responses related to these books, were utilised. Within this framework, the selected illustrated children's books were shared with the participants, and then the students were requested to give answers to questions related to the books. The responses given by the participants were analysed with the descriptive analysis technique.

\section{Results}

In the study, three books were selected from among award-winning illustrated children's books, depending on their inclusion of a "low-medium-high" number of emotions. Of the selected books, the book named "Köstebek Kuki" contained the highest number of emotions, followed by "Piraye'nin Bir Günü" in second place and "Bütün Gün Esneyen Prenses" in third place. In these three books, it was seen that the emotions of "joy, sadness, astonishment, affection and anger" were mostly included in the illustrations, while emotions like "fear, curiosity, worry, derision, excitement and regret" mostly appeared in the texts. When readers' responses related to the illustrated children's book named "Köstebek Kuki", which contained a high number of emotional states, were examined, it was seen that the majority of participants (52.2\%) gave text-based answers. A significant percentage of students (27.3\%) answered the questions by adding their personal opinions and feelings. The feeling of "happiness" was determined to be the emotion most frequently reported among the views of the participants regarding the text and illustrations in the book named "Köstebek Kuki". When readers' responses related to the illustrated children's book named "Piraye'nin Bir Günü", which contained an average number of emotional states, were examined, it was seen that the majority of students $(56.4 \%)$ gave text-based answers. It was observed that the highest percentage of students $(26.9 \%)$ gave written responses aimed at understanding the characters. The feeling of "astonishment" was determined to be the emotion most frequently reported among the views of the participants regarding the text and illustrations in the book named "Piraye'nin Bir Günü”. When readers' responses related to the illustrated children's book named "Bütün Gün Esneyen Prenses", which contained a low number of emotional states, 
were examined, it was seen that over half of the students participating in the study $(53.7 \%)$ gave reader-based answers. The highest percentage of students (37.2\%) answered the questions by adding their personal opinions and feelings. The feeling of "sadness" was determined to be the emotion most frequently reported among the views of the participants regarding the text and illustrations in the book named "Bütün Gün Esneyen Prenses".

\section{Discussion and Conlusion}

This study, which examined reader responses of second-grade primary students to illustrated children's books containing different emotional states, was constructed on Rosenblatt's reader response theory. Three books were selected from among award-winning illustrated children's books depending on their inclusion of a "low-medium-high" number of emotions, the books were read to the students, and readers' responses were obtained. Of the selected books, the book named "Köstebek Kuki" contained the highest number of emotions, followed by "Piraye'nin Bir Günü" in second place and "Bütün Gün Esneyen Prenses" in third place. In the study, which was conducted with the aim of observing what kind of changes in reader responses were caused by quantitative variation in emotional states, it was clearly revealed in the findings obtained from the analyses that a change of text can cause a change in readers' responses. When the responses given by the participants to the books were evaluated together, it was seen that the responses related to the first two books were mostly text-based, while the responses to the third book were mostly reader-based. The findings clearly show that the meanings established can change with a change of text. Another point on which the study focuses is whether or not the emotional states presented in the books were understood by the participants, and how the main character was perceived by the readers to feel these emotions towards his/her experiences. The analyses made for this purpose reveal that in the "Köstebek Kuki" book, the feeling of "happiness" came to the fore, while in the books named "Piraye'nin Bir Günü" and "Bütün Gün Esneyen Prenses", the feelings of "astonishment" and "sadness", respectively, emerged as the main emotions. It was seen that the emotions that came to the fore in the books corresponded with the answers given by the students. Rosenblatt (1994) stated that we read for two purposes, namely knowledge and aesthetics, while in children, it is aesthetic reading that develops reading for pleasure and the reading habit. The studies (e.g., Ateş, 2011) and our experiences show that in our schools, we generally read to obtain information. However, even if reading is definitely to be carried out for information purposes, that is, if the intention is to address the message given in the book, it is also possible to realise this through emotions. This prediction can at the same time be evaluated as a recommendation for both implementation and research. 